\title{
Improving gully density maps for modelling water quality within Great Barrier Reef Catchments
}

\author{
$\underline{\text { S.D. Darr }}^{a}$ and M.J. Pringle ${ }^{b}$ \\ a Department of Natural Resources and Mines, Queensland \\ ${ }^{b}$ Department of Science, Information Technology and Innovation, Queensland \\ Email: shawn.darr@dnrm.qld.gov.au
}

\begin{abstract}
Fine-sediment has been shown to have a detrimental impact on water quality across the Great Barrier Reef (GBR). Gully erosion is one of the dominant sources of fine-sediment loads to the GBR, in particular from the Burdekin and Fitzroy basins. Significant funding has been allocated across the GBR catchments to reduce sediment erosion from gullies. Modelling the relative fine-sediment contribution from gully erosion, and assessing the potential water quality improvement due to investment in gully remediation projects within GBR catchments, is reliant on accurate maps of gully density. Hence, techniques that improve mapping of gully density are essential for improving the quality of inputs into catchment models, and will ultimately lead to improved modelled load estimates and better representation of the impact of remediation programs on sediment loads that are delivered to the GBR.
\end{abstract}

Previous attempts to map gully density within the GBR catchments have been conducted by either intensively mapping gully erosion for relatively small isolated areas where gullies are prominent, or by defining the extent of gully erosion at a number of sample sites and then using predictive models to estimate gully density across much larger areas. Due to scale limitations, low accuracy or limited geographic extent, both these approaches have produced maps with limited usefulness for modelling water quality improvements. Consequently there is a need for a methodology that can improve the confidence in gully density maps over broad areas, in a timely fashion, and at a spatial scale that enables the modelling of water quality improvements due to on-ground investments, and allows prioritising of remediation strategies in the GBR.

This paper outlines a repeatable process that allows an operator to map the presence or absence of gully erosion within a grid cell, using custom-built geographic information system (GIS) tools, aerial photography and uniform grids. Initially, a number of catchments in the Fitzroy and Burdekin basins were mapped using this approach to improve baseline model inputs for gully erosion. Over the past three years $125000 \mathrm{~km}^{2}$ have been mapped using this grid-based presence mapping (GBPM) approach.

Stage two of the work combined the grid-based mapping with a range of landscape attributes such as slope, distance-to-stream and soil erodibility to produce a predictive model that has the ability to generate gully density maps for all GBR catchments.

Finally, the maps from both processes were compared against ground-based observations and previously published estimates of gully density, to determine if these approaches delivered improved inputs for catchment models. Comparison of grid-based gully erosion mapping against ground-based observations show that the grid-based mapping improves the accuracy of the maps compared with previous mapping approaches. The grid-based mapping method developed in this project provides an effective way of capturing gully density data across broad areas. Combining grid-based mapping with predictive modelling enables the acceleration of gullydensity mapping.

Keywords: $\quad$ Source catchments, water quality, Great Barrier Reef, gully erosion 


\section{INTRODUCTION}

Declining marine water quality in the Great Barrier Reef (GBR) lagoon has been recognised as one of the most significant threats to the long-term health of the GBR. The export of fine-sediment from adjacent catchments contributes to the decline of marine water quality and gully erosion is considered to be the largest contributor of fine-sediment export to the GBR receiving waters (Brodie et al. 2013).

To halt and reverse the decline in water quality, the Australian and Queensland governments have developed the Reef 2050 Water Quality Improvement Plan, which builds on earlier iterations of Reef Plan (2009 and 2013). The plan provides significant funding to improve water quality through improved land management practices in GBR catchments (Anon 2013). To evaluate the improvements in water quality from improved management practices, such as gully remediation projects, the Paddock to Reef Integrated Modelling, Monitoring and Reporting Program (P2R) was established. The catchment loads modelling component of this program estimates average annual loads of key pollutants for catchments draining to the GBR, and assesses changes against baseline levels due to improvements in land management practices. As well as reporting progress against water quality targets, the models are used to guide investment priorities.

Modelling the relative fine-sediment and nutrient contribution from gully, hillslope and streambank erosion is dependent on information being available that accurately describes the landscape, climate and management practices. Present knowledge of gully locations, density and volumes is limited for GBR catchments. The need to improve the quality of input data layers for P2R such as gully erosion has been recognised as a priority by several internal government and external independent reviews (QAO 2015, EHP 2014).

A number of studies have undertaken spatial mapping of gullies in the GBR catchments over relatively small areas (1 to $25000 \mathrm{~km}^{2}$ ) using high-resolution imagery or Light Detection and Ranging (LiDAR) data. These methods cannot be easily implemented at basin or regional scales because of the time required to map individual gully boundaries or the costs of capturing and processing LiDAR data over such a large area. Therefore it is necessary to investigate alternative options that can provide improved inputs for water quality models over broad areas in a timely fashion.

Catchment and regional scale modelling of gullies has been conducted over a number of locations within the GBR catchments, and include estimates of density and gully erosion risk. From a modelling perspective only those studies that produced gully densities or outputs that can be used to derive density are useful. Hughes et al. (2001), as part of the National Land and Water Resource Audit (NLWRA), mapped gully extents using aerial photography for a small number of sites over coastal Queensland and other locations around Australia. Gully density was predicted over the study area using a rule-based predictive model. Validation of the model showed that the model's predictive ability for coastal Queensland was poor. Because of the extensive spatial coverage the NLWRA gully density map, and the lack of other data, it is currently being used to represent gully location and density for the majority of catchments in the P2R water quality models.

Trevithick et al. (2009) used high-resolution satellite imagery to map gully lengths at strategic locations across the Fitzroy catchment, and then used a statistical model combined with explanatory datasets to infer gully density across the Fitzroy basin. The gully density map produced in this study was considered to be a significant improvement on the NLWRA gully density map produced by Hughes et al. (2001). However, the model was calibrated in the Nogoa catchment, so when the model was extrapolated to the other catchments within the Fitzroy basin, there was a large prediction uncertainty.

Tindall et al. (2014) produced gully density maps for the Burdekin basin by converting gully risk and semiquantitative gully presence maps into densities. The initial maps were created using a combination of visual assessment of high-resolution imagery, spatial-statistical analysis and a predictive model, later work extended this by converting the risk map to a gully density map. Areas that were identified as 'high' and 'very high' gully presence in the gully risk map were refined by visually assessing the presence or absence of gullies using a grid based presence mapping (GBPM) methodology.

In this study, we aim to determine if the GBPM that Tindall et al. (2014) developed can be used to improve gully density maps in reasonable timeframes, and if the GBPM can be used as training data in a predictive model to accelerate the mapping process. We illustrate this approach for mapping gully densities in catchments within the Fitzroy and Burdekin basins, both of which contain significant amounts of gully erosion. 


\section{STUDY AREA}

The Burdekin and Fitzroy basins are the largest contributors to the fine-sediment exported to the GBR. Together they contribute approximately $56 \%$ of the exported load (McCloskey et. al, 2017). Three catchments within these basins were selected to be mapped using the GBPM approach. Catchments were selected because they either have been identified as having high levels of gully erosion, or P2R water quality models predicted significant loads being exported to the GBR, or there is high uncertainty in the gully density maps used in the P2R models. The three catchments selected are shown in Figure 1 and are: the Bowen Broken Bogie (BBB) catchment (Burdekin basin), and the Isaac and Dawson catchments (Fitzroy basin). The three catchments cover an area of $85000 \mathrm{~km}^{2}$, a fifth of the total Reef drainage area.

\section{METHODS}

Two methods were used to develop maps of gully density for the three catchments selected for this study. The GBPM methodology was applied to all three catchments and a predictive model was used to extrapolate a subset of the GBPM in the BBB catchment.

The GBPM was validated against field observations. A comparison between the two mapping techniques was conducted

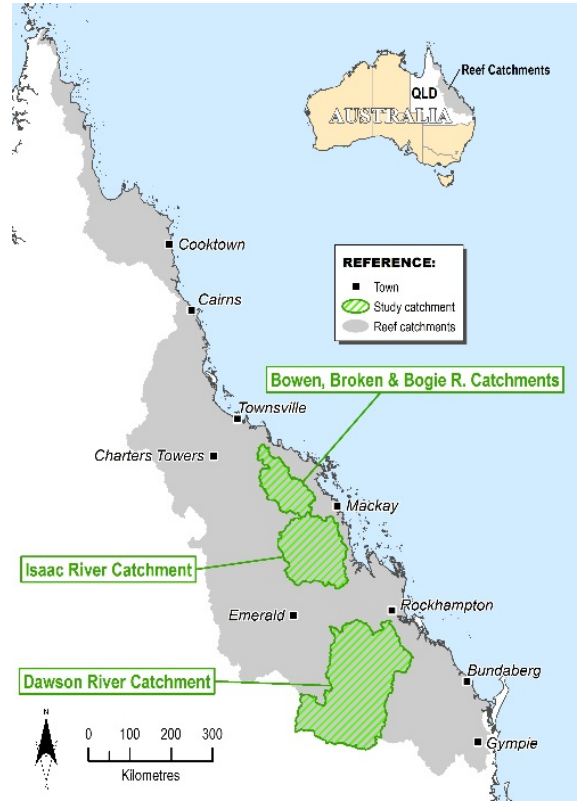

Figure 1. Study area: Bowen Broken Bogie, Isaac and Dawson catchments. where both techniques were applied in the BBB catchment. The results of both techniques were also compared with other broad-scale mapping products that provide coverage over the subject catchments.

\subsection{Grid-based presence mapping}

This work builds on the methodology outlined by Tindall et al. (2014). The desktop process mapped gully erosion using a grid-based approach. "Operators" visually assessed aerial photography within grid cells and identified those cells that had gully erosion present. Two nested grids of different size were created for each catchment on an Australian Albers projection. The first grid contained $100 \times 100 \mathrm{~m}$ cells that were used to identify the presence or absence of gully erosion. The second grid, measuring $1 \mathrm{x} 1 \mathrm{~km}$, was used to record the count of $100 \times 100 \mathrm{~m}$ cells within its boundaries that were mapped as having gully erosion present within them. Each $1 \mathrm{~km}$ grid cell contains one-hundred $100 \mathrm{~m}$ cells. The $100 \mathrm{~m}$ dataset provides a spatial representation of the gully erosion throughout a catchment. The $1 \mathrm{~km}$ data are used to infer the density of gully erosion for use within P2R water quality models.

Figure 1 shows an example of the mapping process using $100 \times 100 \mathrm{~m}$ grid cells. Any cell that contains gully erosion, irrespective of the quantity or erosion, is mapped as having gully erosion present within it. In the example cells B, C and D would be mapped as having gully erosion present.

To ensure consistency between operators and reduce the subjective nature of the classification process, a set of mapping guidelines was developed. The guidelines (Darr et al. 2014) contain the definition of gully erosion and includes rules and examples to assist operators to make consistent decisions.

Operators are allocated small sections of a catchment to map. To ensure consistency, each section is checked by a second operator. Once mapping and quality-checking is complete, the data are incorporated into a central database. A custom-built tool for ArcGIS ${ }^{\circ}$ has been developed to simplify the technical components of the mapping process, and to enhance productivity. The tool allows operators with little or no experience with geographic information systems to be involved in the project.

At the completion of a catchment, gully density, measured in kilometres of gully erosion length per square kilometre $\left(\mathrm{km} / \mathrm{km}^{2}\right)$, was calculated. This was achieved by measuring the length of gully erosion in a random sample of $100 \mathrm{~m}$ cells. The average gully length was calculated. Then, for each 1 $\mathrm{km}$ cell, the count of $100 \mathrm{~m}$ cells that contained gully erosion was multiplied

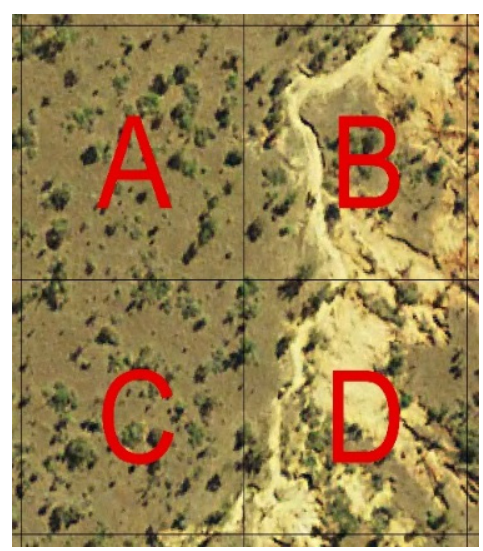

Figure 2. Example $100 \mathrm{~m}$ grid. Cells B, C and D contain gully erosion. Cell A does not. 


\subsection{Modelling}

A modelling approach was investigated to assess its ability to accelerate the labour-intense mapping program. The BBB catchment was selected to test the ability of a statistical model to satisfactorily predict gully density, based on a subsample of GBPM used as training data for the model.

Of the $12173 \mathrm{~km}^{2}$ mapped using the GBPM approach, $n=10331 \mathrm{~km}^{2}$ cells were subsampled to serve as training data. Gully count formed the response variable for modelling. Count-data are generally modelled with a Poisson distribution, but in this situation it was more useful to find a transformation of the distribution that resulted in an approximately normal distribution, as this would open the possibility for convenient spatial interpolation. The explanatory variables for the model included spatially exhaustive information related to vegetative cover, geology, terrain and terrain derivatives, stream characteristics, and the components of the Universal Soil Loss Equation. In total there were 24 explanatory variables. The explanatory variables were kept at their native spatial resolutions, masked, and then intersected with the extent of each $1 \mathrm{~km}$ cell of the response variable.

A random forest, made with 1000 trees, was used to rank the importance of each explanatory variable to the variation in the response. A subset of only the few most important explanatory variables was used herein.

A regression tree was then used to model the response variable as a function of the subset of explanatory variables. This alone is a predictive model that can be used to extrapolate gully count, but it is possible to go one step further, by considering the spatial variability of the tree's residuals. Pringle et al. (2016) showed how a regression tree and its residuals can be re-estimated as a linear mixed model, a process which effectively 'spatialises' the regression tree. The key assumption of the hybrid regression tree-linear mixed model (RTLMM) is that the residuals are approximately normally distributed. Predictions of the RT-LMM, backtransformed if necessary, comprise the trend (obtained from the regression tree), and a correction to the trend obtained by simple kriging. An upper and lower $95 \%$ prediction interval for each unsampled location can be estimated, which ultimately enables models to be run with different input scenarios.

The predictions of the RT-LMM were compared with the observed gully counts of the remaining $1 \mathrm{~km}$ cells.

Similar to the process that was performed for the GBPM, the linear gully density was calculated by multiplying the predicted gully count of each $1 \mathrm{~km}$ cell by the calculated average length of gully erosion.

\subsection{Gully density comparison}

A preliminary comparison of the map results was made by comparing the $100 \mathrm{~m}$ gully presence maps with field-based observations. The field observations were made as part of a road side survey of gully erosion and stable drainage lines. The surveys were conducted in December 2016 and May 2017 for the Isaac catchment and the northern section of the Dawson catchment. A historical survey collected in May 2006 was used to assess the mapping for the BBB catchment. In total 303 observations were collected for this preliminary assessment. Of these, 228 were of gully erosion sites and 75 of stable drainage lines.

The GBPM gully density map was also compared with the map produced from the RT-LMM. Each prediction was compared with the mapped data and plotted on a scatterplot. Model training data were removed for this comparison.

Finally, the gully density maps derived from the GBPM and the RT-LMM were also compared with other broad scale maps (Hughes et al. (2001), Trevithick et al. (2009), and Tindall et al. (2014)) produced for the GBR in regard to the range of densities, the median gully density and total length of gully erosion.

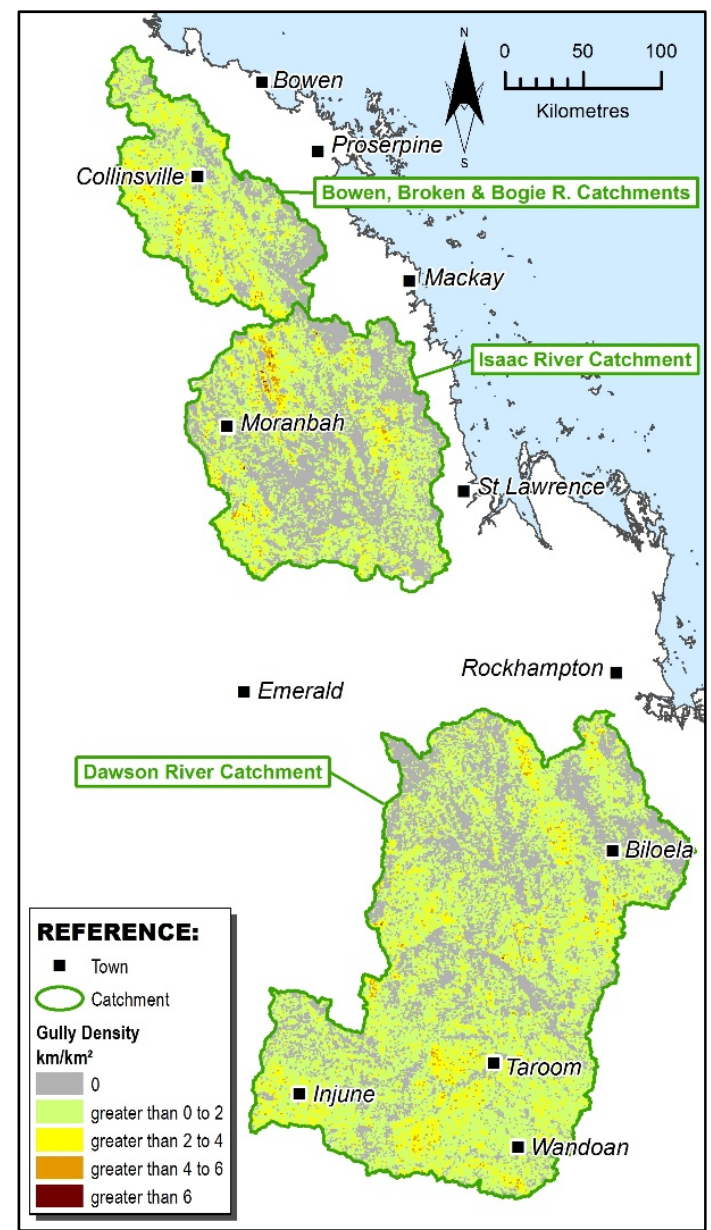

Figure 3. Gully density map of the study catchments (kilometres of gully length per square kilometre) 


\section{RESULTS}

Figure 3 shows the resultant GBPM gully density map produced by converting the $1 \mathrm{~km}$ gully presence count to a gully density. The highest single gully density mapped was $8.3 \mathrm{~km} / \mathrm{km}^{2}$ in the Isaac catchment and coincided with an area of generally high gully densities in the northern part of the catchment. High gully densities were mapped throughout the BBB catchment on the western side of the Bowen River, throughout the northern and western parts of the Isaac catchment and scattered throughout the Dawson catchment. Low or no gully erosion occurred on the eastern side of the Broken River in the BBB catchment and throughout the central and far eastern sections of the Isaac catchment. Approximately $29000 \mathrm{~km}^{2}$ (33\%) of the

Table 1. Error Matrix for the $100 \mathrm{~m}$ gully presence mapping of the Bowen Broken Bogie, Isaac and Dawson catchments.

\begin{tabular}{|r|l|r|r|r|r|}
\hline \multirow{2}{*}{} & \multicolumn{5}{|c|}{ Field Observation } \\
\cline { 2 - 6 } & Glass & Gully & \multicolumn{1}{l|}{$\begin{array}{l}\text { No } \\
\text { Gully }\end{array}$} & \multicolumn{1}{c|}{ Totals } & $\begin{array}{l}\text { Users } \\
\text { Accuracy }\end{array}$ \\
\cline { 2 - 6 } & Gully & 192 & 3 & 195 & $98 \%$ \\
\cline { 2 - 6 } & No Gully & 37 & 71 & 108 & $65 \%$ \\
\cline { 2 - 6 } & Totals & 229 & 74 & 303 & \\
\cline { 2 - 6 } & $\begin{array}{l}\text { Producers } \\
\text { Accuracy }\end{array}$ & $84 \%$ & $96 \%$ & & $\begin{array}{r}\text { Total } \\
87 \%\end{array}$ \\
\hline
\end{tabular}
mapped area contained no gully erosion.

An accuracy assessment was conducted for the mapped $100 \mathrm{~m}$ presence data by comparing mapped cells with field observations. The error matrix that was produced is shown in Table 1. Accuracy is summarised in terms of total accuracy and users and producers accuracies. Kappa was 0.69 which represents moderate agreement between the map and the ground-truthed sites.

The overall accuracy of the mapped data compared with the field observations was $87 \%$, which is considered to be a good result. The mapped data agreed well with field observations where drainage lines contained no gully erosion. However, the mapping approach is less accurate identifying gully erosion. A producers accuracy of $65 \%$ for cells mapped as having no gully erosion indicates many cells that were mapped as no gully should have been mapped as having gully erosion present. Therefore the map underrepresents gully erosion.

A comparison of the preliminary RT-LMM results compared to the GBPM show that the model is not strongly biased in either direction (Figure 4).

A final comparison was made between the results from the mapping and modelling approaches against previous studies. Table 2 shows these results for all three study catchments.

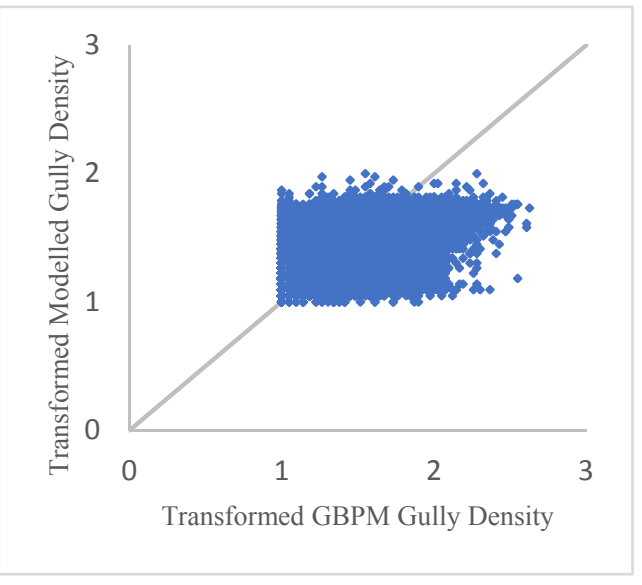

Figure 4. Scatterplot of transformed gully density for GBPM and modelled data.

The NLWRA data consistently has the lowest estimate for all measures. The GBPM and RT-LMM data produce similar statistics for the BBB catchment while the estimate by Tindall (2014) produces a much higher estimate of the total gully length for the BBB. For the Isaac catchment the Trevithick et Al. (2009) estimate is higher than the GBPM estimate of total gully density. Both produce a similar estimate of total gully length for the Dawson catchment.

\section{DISCUSSION}

\subsection{Grid-based presence mapping}

The results of the accuracy assessment show that the GBPM has the ability to accurately capture the location of gully erosion at a spatial resolution of 1 ha. Preliminary validation of the mapped data indicates the mapping approach is able to achieve an acceptable accuracy level of $87 \%$.

The error matrix indicates that the largest misclassification occurred where gully erosion was not mapped but should have been. Of the 37 locations that had gully erosion present in the field but were mapped incorrectly, the majority (60\%) occurred under areas of dense vegetation. For 17 sites the foliage projective cover exceeded $25 \%$ and neither bare ground or the gully incision could be seen in the imagery. At an additional five sites the vegetation was not as thick (foliage projective cover $>12 \%$ and $<25 \%$ ) and some bare ground could be seen in the imagery but the tree cover and shadowing from trees made it difficult to confirm that a gully incision was present. This finding is similar to the results of Trevithick et al. (2009) who found that their maps 
Darr and Pringle, Improving gully density maps for modelling water quality within GBR Catchments

underestimated gully erosion in highly vegetated areas.

Table 2. Comparison of gully density values from the mapped, modelled and other studies for the Bowen Broken Bogie, Isaac and Dawson catchments

\begin{tabular}{|c|c|c|c|c|c|c|c|c|}
\hline \multirow[b]{2}{*}{ Catchment } & \multirow[b]{2}{*}{ Source } & \multicolumn{5}{|c|}{ Gully Density $\left(\mathbf{k m} / \mathbf{k m}^{2}\right)$} & \multirow{2}{*}{$\begin{array}{c}\text { Total } \\
\text { Gully } \\
\text { Length } \\
(\mathbf{k m})\end{array}$} & \multirow[b]{2}{*}{$\begin{array}{l}\text { Area } \\
\left(\mathbf{k m}^{2}\right)\end{array}$} \\
\hline & & Min. & Max. & Range & Median & $\begin{array}{c}\text { Interquartile } \\
\text { Range }\end{array}$ & & \\
\hline \multirow{4}{*}{$\begin{array}{c}\text { Bowen } \\
\text { Broken } \\
\text { Bogie }\end{array}$} & GBPM $1 \mathrm{~km}$ & 0 & 6.4 & 6.4 & 0.7 & 1.6 & 11777 & 11728 \\
\hline & RT-LMM Median & 0 & 6.7 & 6.7 & 0.9 & 1 & 11047 & 11441 \\
\hline & Tindall et al. (2014) & 1 & 7 & 6 & 3 & 1 & 24600 & 9150 \\
\hline & NLWRA & 0 & 2.1 & 2.1 & 0.2 & 0.2 & 2494 & 8596 \\
\hline \multirow{3}{*}{ Isaac } & GBPM $1 \mathrm{~km}$ & 0 & 8.3 & 8.3 & 0.3 & 1.2 & 16302 & 22236 \\
\hline & Trevithick et .al (2009) & 0 & 5 & 5 & 0.8 & 1.4 & 24041 & 22358 \\
\hline & NLWRA & 0 & 0.4 & 0.4 & 0.1 & 0.1 & 2562 & 20497 \\
\hline \multirow{3}{*}{ Dawson } & GBPM $1 \mathrm{~km}$ & 0 & 6.8 & 6.8 & 0.5 & 1.3 & 41703 & 50742 \\
\hline & Trevithick et .al (2009) & 0 & 7.5 & 7.5 & 0.7 & 0.5 & 48711 & 50761 \\
\hline & NLWRA & 0 & 1.4 & 1.4 & 0.1 & 0.3 & 7672 & 47581 \\
\hline
\end{tabular}

The GBPM project currently has an average of 10 active staff per month mapping gully erosion. Their effort equates to approximately 1.4 full time equivalents per month. On average $4200 \mathrm{~km}^{2}$ is mapped and qualitychecked per month. If this mapping rate were maintained it would take approximately five years to map the remaining $300000 \mathrm{~km}^{2}$ of the GBR catchments. This is more efficient than field work or mapping the gully extents manually but it is not a quick process for basins the size of the Fitzroy and the Burdekin.

\subsection{Regression tree-linear mixed model}

Of the 24 explanatory variables, only four were considered important enough to be useful for a regression tree: the standard deviation of annual rain, the 'relief' factor of the Universal Soil Loss Equation, long-term foliage projective cover (FPC), and stream density. Generally, larger values of FPC were associated with smaller values of gully density. The largest values of gully density were associated with $\mathrm{FPC}<15 \%$, stream densities $>1.33 \mathrm{~km} / \mathrm{km}^{2}$, and standard deviation of rain $<256 \mathrm{~mm}$. On re-fitting of the regression tree as a linear mixed model, the assumption of normally distributed residuals was met.

We intend to re-run the linear mixed modelling aspect of this study with different sampling intensities to determine the optimal number of GBPM training samples required to produce satisfactory results.

\subsection{Gully density comparison}

Comparing the GBPM to the RT-LMM results shows that the modelling approach produces similar statistics to the mapped data. Ranges of gully density and total gully length are similar and the scatter plot confirms that there is no strong bias of the modelled estimate. Spatially the two maps are similar however it is obvious that the RT-LMM behaves similarly to other predictive models, in that very few areas with no gully erosion are predicted whereas GBPM identified $27 \%$ of the BBB with no gully erosion. Overall there is good agreement between the GBPM and the RT-LMM results. If these results can be replicated across other catchments then the RT-LMM approach offers the ability to accelerate the mapping of gully densities in the GBR.

The comparison between GBPM, RT-LMM and previous studies show that the NLWRA underestimates gully density compared to all other studies by a factor of 5 to 10 times indicating that it may substantially underpredict gully density. The estimate made by Tindall et al. (2014) for the BBB is over double the estimate of the GBPM which indicates that it may be an overestimate of the true gully density.

There are many statistical similarities between the work of Trevithick et al (2009) and the GBPM. Spatially, however, there are significant differences between the two. In the Isaac and Dawson catchments the GBPM maps large parts of the catchments, approximately 35\%, as containing no gullies whereas Trevithick et al (2009) maps very few areas with no gully erosion (1\%). The differences are not as pronounced at higher gully 
density rates. The locations of high gully density are inconsistent between the maps, with some areas in agreement and others not. We consider the GBPM to be an improvement on the maps produced by Trevithick et al (2009).

Because the GBPM assesses aerial photography, and gully erosion needs to be observed, we consider that GBPM provides a better estimate of gully densities than the maps produced by previous modelling methods discussed in this paper. The accuracy assessment shows that although not all gullies were mapped due to dense vegetation cover, of those that were mapped using the GBPM methodology, $98 \%$ that were visited in the field were correctly identified.

\section{CONCLUSIONS}

This project has demonstrated that the GBPM approach is able to provide improved estimates of gully density for the GBR compared to the currently available broad scale data that was produced by predictive models. Initial accuracy assessment results indicate that the GBPM is able to very accurately identify gully erosion in both open and lightly vegetated areas. However the process is slow. Results of the RT-LMM approach based on GBPM training data demonstrates that it can produce similar gully density maps to the GBPM and offers the potential to accelerate the mapping of gully densities throughout the GBR catchments.

We recommend that maps produced by the GBPM or RT-LMM approaches outlined in this paper should be used to replace the data currently used in P2R models. The replacement of the current data with GBPM or RTLMM maps should see an improvement in modelled load estimates and better representation of the efficacy of remediation programs on sediment loads that are delivered to the GBR.

\section{REFERENCES}

Anon. (2013). Reef Water Quality Protection Plan 2013. Reef Water Quality Protection Plan Secretariat.

Brodie, J., J. Waterhouse, B. Schaffelke, F. Kroon, P. Thorburn, J. Rolfe, J. Johnson, K. Fabricius, S. Lewis, M. Devlin, M. Warne, L. McKenzie, (2013). 2013 Scientific Consensus Statement. Land Use impacts on Great Barrier Reef water quality and ecosystem condition. The State of Queensland, Brisbane.

Darr S., D. Tindall, J. Ross, B. Stone, B. Marchand, (2014) Guidelines for catchment scale gully erosion mapping in Queensland: Principles, procedures and definitions. Unpublished report.

Department of Environment and Heritage Protection (EHP) 2014, Reef Water Quality Unit 2014: Reef Water Quality Research, Development and Innovation Strategy 2014/15 - 2018/2019.

Hughes, A.O., I.P. Prosser, J. Stevenson, A. Scott, H. Lu, J. Gallant, (2001). Gully Erosion Mapping for the National Land and Water Resources Audit. Technical Report 26/01. CSIRO, Land and Water, Canberra, Australia.

McCloskey, G.L., D. Waters, R. Baheerathan, S. Darr, C. Dougall, R. Ellis, B. Fentie, L. Hateley, (2017). Modelling pollutant load changes due to improved management practices in the Great Barrier Reef catchments: updated methodology and results - Technical Report for Reef Report Cards 2015, Queensland Department of Natural Resources and Mines, Brisbane, Queensland.

National Committee on Soil and Terrain (Australia) (2009). Australian soil and land survey field handbook (3rd ed). CSIRO Publishing, Collingwood, Vic.

Pringle M.J., D. E. Allen, T. G. Orton, T. F. A. Bishop, D. W. Butler, B. K. Henry and R. C. Dalal (2016) Effects of land-use change and management on soil carbon and nitrogen in the Brigalow Belt, Australia: II. Statistical models to unravel the climate-soil-management interaction. The Rangeland Journal. 2016(38) 453466.

Queensland Audit Office (QAO) 2015, Managing water quality in the Great Barrier Reef catchments Report 20: $2014-15$

Tindall, D., B. Marchand, U. Gilad, N. Goodwin, R. Denham, S. Byer, (2014). Gully mapping and drivers in the grazing lands of the Burdekin catchment - RP66G Synthesis Report, Department of Science, Information Technology, Innovation and the Arts, Brisbane, Queensland.

Trevithick, R., M. Herring, C. Dougall, R. Denham, M. Pringle, (2009). Gully density mapping and modelling for the Fitzroy Basin, Queensland, Australia. Queensland Department of Natural Resources and Water, Queensland Department of Natural Resources and Water, Brisbane, Qld. 